\title{
G8 Summit: a final test of credibility
}

Published at www.cmaj.ca on June 25

I nternational health advocates expect world leaders attending the Group of Eight Summit in Huntsville, Ontario from June 25-26 to pledge substantial new sums of money for maternal and child health programs.

But veteran G8 observers warn that real investments will likely not flow as freely as the self-congratulatory rhetoric that will erupt if huge new commitments are made in Muskoka.

In fact, the 25-year history of the G8 does not augur well for Canada's hopes of strengthening health systems in the world's poorest countries, where an estimated 350000 mothers and nine million children die annually from easily preventable causes (www.cmaj.ca/cgi/doi/10 $.1503 /$ cmaj.109-3250 and www.cmaj.ca /cgi/doi/10.1503/cmaj.109-3300).

Aid groups say a \$24-billion pledge is required to achieve the reductions in maternal and child deaths needed to achieve targets set as part of the Millennium Development Goals which were agreed to by Canada and its G8 siblings, along with 170 other nations and major development organizations, in the year 2000.

And even if the pledges are made, it's no guarantee that the required funds will flow as, in recent years, many G8 health pledges proved hollow.

It's a problem that International Cooperation Minister Bev Oda, Canada's point person on G8 health commitments, alluded to in an address earlier this month. She noted that the forum made twice as many commitments on humanitarian causes since 2000 as it had in its previous years of existence, but all too often makes headlines with promises that its member nations have no plans of honouring.

"Donor countries should be held accountable for paying for what you commit in a timely way," Oda said.

Oda's acknowledgement of the G8's sincerity problem is inescapable given that the group, whose members currently finance about $80 \%$ of international development expenditures, has failed to deliver on an array of health promises.

In 2005, for example, the forum agreed to achieve full universal access to HIV/AIDS treatment by 2010, and to expand aid budgets by $\$ 50$ billion by 2010.

At this point, notes Jeffrey Sachs, special advisor to the United Nations secretary general on the millennium development goals, the G8 nations are about $\$ 30$ billion short on the latter pledge. "Strangely enough, of all of the areas of the world that were promised help, it's Africa, the very poorest part of the world, the one that is most in need of help and the one that's taken dramatic steps to be able to use assistance effectively, that has not received the promise," he adds.

Similarly, the G8 nations promised in 2007 in Norway to devote US\$1.8 billion to achieve universal access for

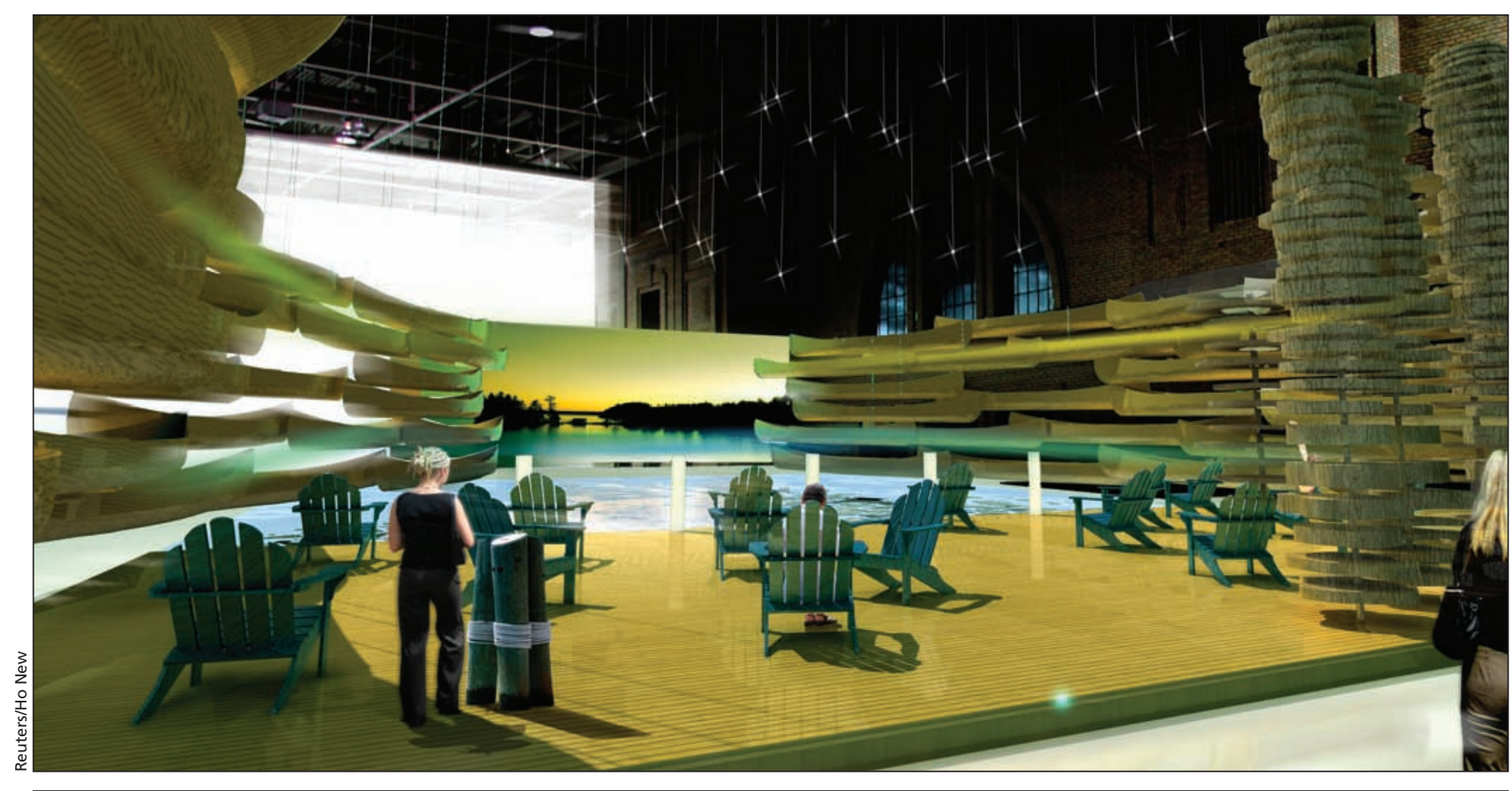

An artist's rendering of an artificial lake at the press centre for the forthcoming G8/G20 summits. 
children to HIV/AIDS treatment by 2010.

"The G8 has not reached the target," says Robin Lennox, a researcher with the G8 research group at the University of Toronto in Ontario. While "the number of children initiated on antiretroviral treatment has increased significantly over the past few years," he notes, UNICEF estimates that an additional US\$649 million is needed to deliver on the promise.

Lennox also notes that despite a \$1.5-billion pledge in 2007 "to reduce the gaps in the area of maternal and child health care and voluntary family planning," the World Health Organization (WHO) estimates that at least US\$30 billion more will be needed before 2015 to achieve the goal.

Such anomalies are not likely to faze world leaders.

"Prime Minister [Stephen] Harper has called this summit the accountability summit," Sachs noted in a conference call with journalists in June. But he frets that the Muskoka summit will fail to even acknowledge previous shortfalls.

"They are probably going to try to duck this," he predicts. "In my view, this would essentially be the end of the G8 as a credible instrument."

Others argue that G8 global health promises are invariably sidelined by economic self-interest.

"The overall irony is that the members of the G8 club have done more than any others to impoverish Africa," says Gerald Caplan, author and former consultant for such organizations as UNICEF and WHO. "Even while the G8 leaders grandstand on aid, they persistently reinforce trade policies that entirely subvert whatever humanitarianism they attempt."

As further evidence of G8 self-interest, Neil Andersson, founder of the Mexico-based Centro de Investigación de Enfermedades Tropicales, points to the Alma Ata Declaration of 1978, in which global health leaders promised more support for primary health care - and later endorsed sweeping cuts to social programs across the developing world in order to force debt repayments.

The G8's role in global health has always been suspect, argues Ron Labonte, Canada Research Chair in globalization and health equity at the University of Ottawa in Ontario. "I wouldn't regret seeing them disappear."

It would make more sense to simply vest the WHO with the authority and the resources to tackle maternal and child health, Labonte says, adding that the G8's role should be limited to finding money for the WHO through taxation and other financial measures. Instead, while WHO "has had its contributing budget frozen since the 1990s," G8 ministers usurp the headlines. - Paul Christopher Webster, Toronto, Ont.

DOI:10.1503/cmaj.109-3303 